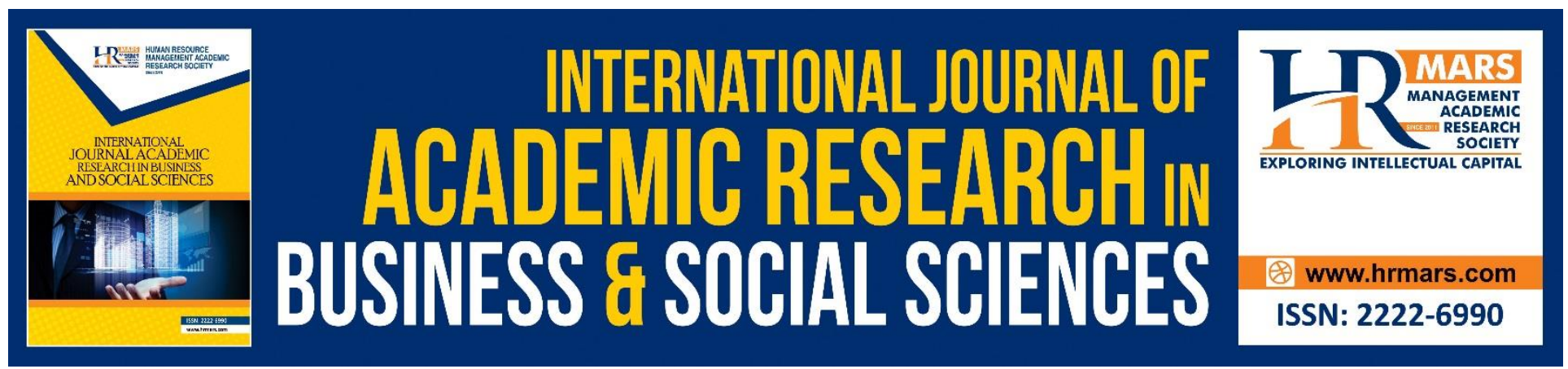

\title{
Women's Struggle for Reproductive Rights from the Islamic Worldview
}

Siti Khatijah Ismail, Siti Fatimah Salleh, Rahimah Embong, Normadiah Daud, Nadhirah Nordin

To Link this Article: http://dx.doi.org/10.6007/IJARBSS/v8-i11/4913

DOI: 10.6007/IJARBSS/v8-i11/4913

Received: 28 Oct 2018, Revised: 22 Nov 2018, Accepted: 26 Nov 2018

Published Online: 28 Nov 2018

In-Text Citation: (Ismail, Salleh, Embong, Daud, \& Nordin, 2018)

To Cite this Article: Ismail, S. K., Salleh, S. F., Embong, R., Daud, N., \& Nordin, N. (2018). Women's Struggle for Reproductive Rights from the Islamic Worldview. International Journal of Academic Research in Business and Social Sciences, 8(11), 421-436.

Copyright: (c) 2018 The Author(s)

Published by Human Resource Management Academic Research Society (www.hrmars.com)

This article is published under the Creative Commons Attribution (CC BY 4.0) license. Anyone may reproduce, distribute, translate and create derivative works of this article (for both commercial and non-commercial purposes), subject to full attribution to the original publication and authors. The full terms of this license may be seen

at: http://creativecommons.org/licences/by/4.0/legalcode

Vol. 8, No. 11, 2018, Pg. 421 - 436

Full Terms \& Conditions of access and use can be found at http://hrmars.com/index.php/pages/detail/publication-ethics 


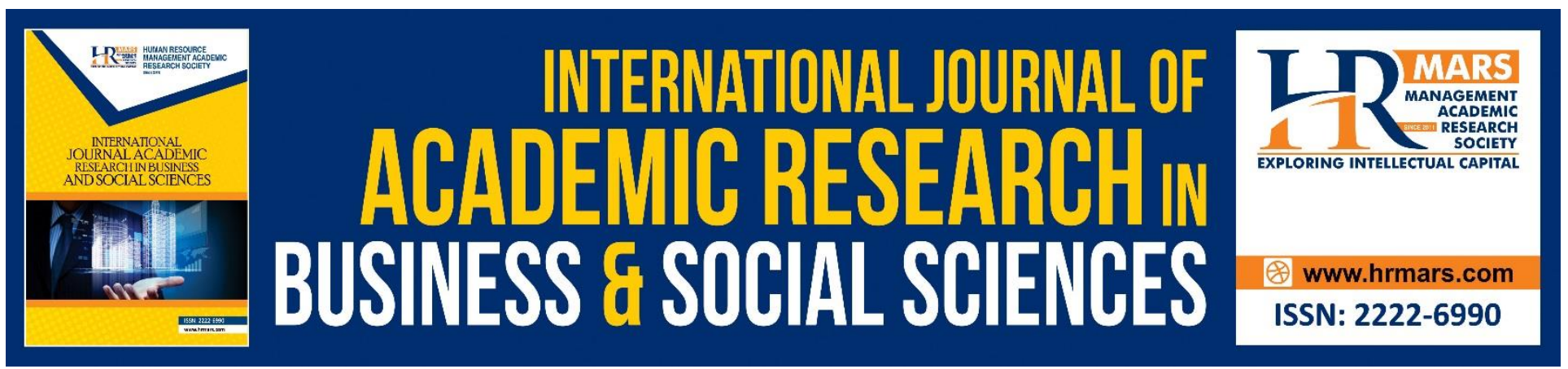

\title{
Women's Struggle for Reproductive Rights from the Islamic Worldview
}

\author{
*Siti Khatijah Ismail'1 , Siti Fatimah Salleh², Rahimah Embong ${ }^{3}$, \\ Normadiah Daud ${ }^{4}$, Nadhirah Nordin ${ }^{5}$ \\ $1,2,3,4,5$ Faculty of Islamic Contemporary Studies, Universiti Sultan Zainal Abidin \\ Terengganu, Malaysia
}

\begin{abstract}
This article aims to analyze the issue of women's struggle for their reproductive rights from the Islamic worldview. The struggle of women to the reproductive rights that has been propagated in the west recently is spreading among communities in Malaysia. The reproductive rights such as the rights to abortion, choose maternity, determination of child's gender and number of children become common issues related to the practices of a woman's private rights. However, this belief brings confusion among Muslims when these practices based on the individual's basic rights failed to achieve the betterment of the women. This seems to manifest the failure of maqasid Shariah (objectives of Islamic law) that is giving benefits and eliminating harm. The struggle for reproductive rights sometimes may violate the fundamental principles of the Holy Qur'an as mentioned in some Quranic verses relating to human rights including for women. The data were obtained from the interpretation of some related Quranic verses as well as the works in the fields of Fiqh (Jurisprudence) and medicine; and interviews with experts in the field of obstetrics. It is found that there are some efforts of striving for reproductive rights based on the human basic rights are contradicting to the fundamental principles of the Holy Quran and need to be prevented from being spread among Muslim community. The understanding of this issue should consider the impact of such practices that will violate maqasid shariah as the underlying foundations of the Malaysian shariah index of health and medical aspects. This article recommends as a guideline to current practices in evaluating women's reproductive rights that is based on a woman's basic rights.
\end{abstract}

Keywords: Women's Rights, Reproductive Rights, the Holy Quran, Maqasid Shariah, Islamic Law, the Quranic Perspective

\section{Introduction}

Women have special and noble position from the Islamic perspective. Their rights have been preserved under Islamic law and recognized in all aspects of life including dealing (muamalah), economy, family, health and not limited to worship only. This is totally different from their condition 
before the coming of Islam which women were treated as objects like goods that can be traded. However, nowadays some women struggle for their rights based on their private rights even some of them are contrary to the general principles of the Holy Quran and maqasid syariah. Hence this article aime to examine the women's struggle for their reproductive rights in the light of the Quranic perspective.

\section{Human Rights Framework}

The God has created human being as the most perfect creation. The combination between soul and body, resulting in complete human beings with feelings, wills, desires, thoughts and actions. Due to this perfection, human beings are free to think and act, free to enjoy numerous God's favor. Human existence is by the will of the Creator. Besides enjoying freedom, man is still limited by the rules of the Creator. Allah reminds mankind in the Holy Quran as follows;

Meaning: Not one of the beings in the heavens and the earth but must come to ((Allah)) Most Gracious as a servant. He does take an account of them (all), and hath numbered them (all) exactly. And everyone of them will come to Him singly on the Day of Judgment.

Maryam, 19: 93-95

This illustrates that man has been created man as a slave to be obedient to the Creator's rules. In addition to being subjected to obedience, human beings are also counted every single action, their daily activities that based on freedom of life on this earth. These rights of freedom include both the rights of individual and society that cover social, economic, political, and religious issues. The right to life is most important for every human being, then the right to continue living.

The struggle for basic rights struggle of women promoted and recognized by the Islam such as the rights of ownership, working, inheritance, marriage, dowry, divorce, hadhanah (custody) harmonious dealing, judgment, education and so on. Such rights are categorized as civil (madani) rights. While the rights to political matters such as freedom of speech, political freedom, political involvement, casting vote, security and protection from any form of exploitation, the right to doing dakwah and jihad, an so forth (AbuFaris, 2000).

All the above-mentioned rights are among the rights of women outlined by Shaiah and need to be preserved. The concept and approaches of these rights should be preserved and meet the standard of Shariah.

\section{Human Rights in the Malaysia}

Human rights have been debated since the proclamation of universal human rights in 1984 . It was pioneered by the united nations that most free countries of the world becoming its members (Hamat, 2007). In the context of Malaysia, Suruhanjaya Hak Asasi Manusia Malaysia (SUHAKAM) had been established under the Human Rights Commission of Malaysia Act 1999, Laws of Malayisa Act 597. Section 2 of this Act defines "human rights" refers to 'fundamental liberties as enshrined in Part II of the Federal Constitution' (Laws of Malaysia Act 597). 
Section 4 (4) of the Act stipulates that it should be given more attention to the Universal Declaration of Human Rights 1948 (UDHR) if the Declaration does not contravene the Federal Constitution. This means that any rights and freedoms not mentioned in Part II but are referred in the UDHR must be considered if there is no contradiction with the Federal Constitution. The function of investigating complaints about human rights violations is subject to the conditions imposed by Section 12 of the Act. Section 12 gives SUHAKAM the authority to initiate an investigation into the alleged transgression of human rights, as well as taking necessary action based on the complaints made. However, SUHAKAM can not investigate complaints that are the subject of pending proceedings of any court of law or have been finalized by the court. The investigation must be stopped if the matter under investigation is brought to court.

The establishment Act has given SUHAKAM the authority to carry out its functions effectively. Under Section 4 (2) of the Human Rights Commission of Malaysia Act 1999, Act 597, SUHAKAM is empowered to foster awareness of human rights and to undertake research by conducting programs, seminars and workshops and to disseminate the research findings. In addition, this body serves to advise government or relevant authorities on complaints against them and recommend to them appropriate measures to be taken as well as to review and confirm any violation of human rights in accordance with the provisions of this Act (Anon, 2018).

The function of SUHAKAM evidently demonstrates its job scope in struggling for human rights and preventing the negligence on such rights. However, the scope of this woman's reproductive rights is privileged to certain groups that deserves to be concerned. This article will elucidate three reproductive rights namely right to abort pregnancy, the right to choose the labour person in charge and the right to choose the labour method.

\section{The Right To Terminate Pregnancy}

Termination of pregnancy from a medical perspective is a procedure to remove the fetus after the pregnancy could not be continued due to maternal safety factor or the fetus condition. Certain methods are used to remove the fetus. Generally, the process of removing the fetus before its maturity period may refer to two different types namely abortion and termination of pregnancy. Nothwithsatnding the process and purpose are removing the fetus, both brought different implications. Abortion is a more extreme term in which it involves an act of immorality and violates ethics even considered as a crime (Tussaripah et. al., 2012). The termination of pregnancy is much more than an action taken after considering the benefits and risks of pregnancy if it proceeds. However, if the process of termination of pregnancy is done with an immoral justification it is considered as a abortion. The right to terminate the pregnancy discussed in this article refers to the termination of pregnancy made on the basis of reproductive rights for a woman. Is this process acceptable if it is made on the basis of a woman's private right?

Studies in England indicate that the abortion can be seen from three aspects, one of these aspects is criminal action, as a therapeutic medical procedure and a popular fertility control method 
(Brookers, 2013). This shows that this issue is not only discussed among Muslim scholars in Muslimmajority countries and even seriously debated among non-Muslim scholars, this abortion is similar with infanticide. However, there are groups who defend the right to make decisions regarding woman's reproductive issues by allowing abortion (Kaczor, 2015). These groups considertThe women's right to abort is the right of choice in terminating pregnancy with any justification. This becomes an issue that challenges the moral, social and cultural values of the society, especially in the context of Malaysia that still has good cultural and ethical practices.

Recent developments show that the trend in Malaysia similar of what is in western countries. The emergence of groups that use media as a medium of advocacy of womens' rights and health in Malaysia. For example, the Malaysian Reproductive Rights Advocacy Alliance (RRAAM) has been established to support women to get better quality pregnancy and abortion services (Anon, 2018) founded on February 2, 2007, fights for women's reproductive rights as well as realizing women's health rights. The question arises is how far this reproductive rights struggle can be practiced in thelight of the Quran.

Women's struggle to be given the right to terminate pregnancy on their own choice is the same by applying for non-therapeutic abortion practices to be justified. Analysis of this struggle from the Islamic, medical and legal perspectives suggests that only termination of pregnancy on therapeutic reasons is justified. The law of terminating pregnancy by abortion is generally illegal as agreed upon by consensus of scholars (al-Hanbali, 1987; al-Ramli, 1967) and is considered as a crime (al-Mani ', 2013) that should be imposed punishment because it has ended one's life or in other words, act of killing or murder.

Even though the spirit has not been blown, the fetus is a living being because it has gone through the process of growth and getting food (al-Barr, 1995) from his mother's nutrition after fertilization between sperm and ovum. His punishment is included in category of al-diyyah almukhaffafah and obliged to pay ghurrah (al-Zuhayli, 2011). This statement is a general provision for the termination of pregnancy according to the Shariah perspective. However, it also considers emergency situations to preserve the mother's life rather than to maintain the fetus if continuing pregnancy. In this regard there is a ruling of rukhsah to prevebt the harm. Therefore, termination of pregnancy is required in certain circumstances after obtaining confirmation from individuals who are experts in this field in line with the divine command to refer to the expert (ahl al-zikr) according to their respective fields of expertise.

In this regard, refering to medical practitioners is a more proactive step towards mere awareness of women's maslahah because the aspect of personal safety is a key aspect compared to other aspects. Thus, the right to end pregnancies that fight for some women is to win with the concept of wellness in medicine only if therapeutic justification is accepted. Therapeutic abortion is to remove the fetus based on medical indication to achieve certain objectives such as saving maternal life. It refers to one form of termination of pregnancy performed due to risk factors. Based on the above terms and their explanations, the issue of termination by this enactment poses a controversy 
INTERNATIONAL JOURNAL OF ACADEMIC RESEARCH IN BUSINESS AND SOCIAL SCIENCES Vol. 8, No. 11, Nov, 2018, E-ISSN: 2222-6990 @ 2018 HRMARS

in the medical, legal or general ethical aspects as it involves the effort to do so and not spontaneously as the term al-ijtihad in Arabic used to describe this act (Ibrahim et al., 1972).

In Malaysia, the number of maternal deaths between 2011 and 2012 recorded by the Malaysian Confidential Inquiry of Maternal Death (CEMD) (Government of Malaysia, 2014) showed that TOP factor did not contribute to high maternal mortality compared to other factors. However, the issue of life makes this matter should be discussed seriously. This priority is clear when many countries take positive steps in addressing maternal mortality as abortions such as contraception, sex education and law-making abortion are prerequisites of making a safe abortion.

In this regard, three appropriate aspects are considered into the struggle for the right to terminate this pregnancy WHICH are aspects of Sharia, medicine and legislation. An analysis of these three aspects demonstrates a clear guideline when examining issues related to women's personal rights in choosing to continue their pregnancy or to end them. According to the Sharia perspective, termination of pregnancy is only permitted if there is a threat factor to the mother's life. Fatwa by the 52th Muzakarah National Fatwa Committee for Islamic Religious Affairs of Malaysia on July 1, 2002 decided that termination of pregnancy is permitted prior 120 days of gestational age if the baby was found to be defective and endangering maternal life such as thalassemia. This permissiblefactor depends on the disability of the baby and at the same time harmful to the mother's life. Thus, the baby's disability merely without giving threat on mother's safety is not permitted to abortion. This is further reinforced by a decision that permits abortion of more than 120 days of gestational age if only this action may save the mother's life. Hence, it is illegal for any form of termination of pregnancey without the justification mentioned earlier.

Similar approaches are identified in other religious teachings such as Christian Roman Catholicism, Hinduism, Buddhism and Jainism. The sanctity of life in Catholic Roman Catholicism prohibits invasion of life even in fetal or embryonic stages except in certain circumstances (Mclean \& Maher, 1983). This principle is extremely emphasized in the teachings of Hinduism and Buddhism that believe in "Ahimsa" (no violence and injury to all life). They not only regard the act of destroying life as a crime but also not destroying animal life even small insects (Chandrasekhan, 1974). Generally, prohibition of abortion according to the Islamic worldview and other religious beliefs manifests the concept of honoring life given by the God. Consequently, human beings have no right to abolish any life but have different approaches to be justified if it is permissible.

From the medical aspect, the issue regarding the termination of pregnancy (TOP) is oftenly discussed in the critical issues of healthcare etiquette. The attachment to the termination procedure with value and ethics is clear when this procedure involves the principle of preserving life from the perspective of sharia. This element is also an oath among nurses as mentioned in the document of the Muslim Medical Practitioner's Oath, the Islamic Code of Medical Ethics or Hippocrates Oath (Mazni \& Anisah, 2011) regardless race or religion of the patient. Hence, it is categorized as critical when it deal with the matter of life and honor. Furthermore, the current challenge makes this issue difficult to be solved. 
Practically, only risky pregnancy either to the mother or the fetus or both will be permitted to perform the TOP procedure. For example, in the case of a mother with chronic high blood pressure or a critical heart disease that can endanger both her mother and her fetus (MacLaren, 1978). Hence, only TOP is permitted merely based on medical or therapeutic reason and is regarded as not contrary to medical ethics. Any reason for the right to end the pregnancy other than that reason will only be detrimental to women and this is contrary to the general principles of the Sharia.

Similarly, this issue is analyzed from legal aspects. Abortion rates in Malaysia are not even closely related to law enforcement factors to ensure safe abortion, but the tendency to make them as legitimate as in other countries can occur on the basis of fighting for human rights. This is because studies have shown that there is a high risk of induced abortion due to factors of economic, social and impoper family planning (Mansureh et.al., 2015). The pro-choice struggle for human rights in TOP in other countries may also influence the circumtances in Malaysia.

With respect to the provisions of the law relating to termination of pregnancy (TOP), Malaysia uses Section 312 of the Penal Code as a provision in dealing with abortion. The provisios under this section is viewed to guarantee the fetus's right to survive (Siti Khatijah \& Mohd Badrol 2013) and in line with the views of the Islamic jurists (fuqaha) who acknowledge the life of fetus. This is clearly explained when a pregnant woman who is sentenced to death can postpone this sentence until she gives birth and bressfeed her child for a certain period of time. Termination of pregnancy is considered a mistake and violates the Code of Professional Conduct issued by the Malaysian Medical Council (MMC)) even considered homicidal crime if done intentionally (Kartina, 2012). This shows that the fetus's right to life is assured in accordance with the law even in the womb. The guarantee of the right to life is honored to a person under Article 3 of the Universal Declaration of Human Rights of the United Nations that has clearly given the right to life to someone (Warren, 1996).

On the other hand, there is a debate relating to the fetus status whether it may be considered a 'being' or not to be protected under Article 3 of the Universal Declaration of Human Rights or Article 5 of the Federal Constitution of Malaysia. Generally, a human rights issue for survival is guaranteed under national law, the Federal Constitution of Malaysia under the title of National Liberation through the provision of Article 5. This Part states that no one can take his life except under law. In addition, the establishment of the Human Rights Commission in 1999 aimed to raise awareness and provide education on human rights issues (Abdul Rahman, 2006).

The above-mentioned legal provisions regarding TOP shows a great legal recognition to ensure the preservation of life in the context of modern written laws. This approach is in line with maqasid al-shari'ah which preserves the life from any harm (mafsadah). Therefore, any form of step to avoid mafsadah is stimultanuously brings maslahah. Hence, the provision of laws related to TOP in Malaysia meets these requirements. For the TOP case to be done because of the mother's'betterment, the law provides for referring to a registered medical practitioner to ascertain how far this procedure is needed. However, more precautionary measures are taken at the 
implementation stage at government hospitals when the views of two specialist must be considered in determining TOP is a must to have taken into account since the risk of continuing pregnancy is greater than its termination such as maternal safety, mental injury and physical health.

In sum, the provision of existing legislation seemed to be sufficiently become a general guide to the TOP to be sought. A holistic approach practiced ensures the wellbeing of pregnant women and fetus when appropriate consideration must be made before deciding to continue the pregnancy or not. Abortion is performed because of the maternal safety factor if the pregnancy continues to be practiced in most states in the United States before 1973. On the contrary in Indonesia there is an approach that prevents this abortion even to save mother's life because it is considered a crime by neglecting mother's life. Allowing it to be done freely for other reasons such as economic and social will create chaotic situation as practiced in the United Kingdom (Stanislaw, Frankoskwi and George, 1987). This development is seen as increasingly inclined towards the struggle of personal rights in making choices to terminate pregnancy. It can spread to other countries including Malaysia if it is not harmonize with religious, ethical, moral and legal controls.

\section{Right to Choose the Delivery Personel}

Delivery personel in this study is referring to individuals who are involved in the birth process either in hospital including delivery at an Alternative Birth Center (ABC), or home birth. It covers specialist doctors, medical doctors, trainees, midwives, nurses, attendants, birth companion or coach like doula. This issue of choosing delivery personel needs to be analyzed because it brings conflict in the community and it becomes sentisitive because it involves the patient's dignity as opposed to other cases of operating procedures such as ophthalmology, orthopedics and neurology. This is because the gender of the delivery personel become a major concern as this case involves the exposure of awrah or intimate parts of women's body.

In this regard, there is a fight for female personel to manage delivery based on the reasons to meet Sharia requirement and the need to preserve the women's dignity. A petition sent to the Head of National Health. Tan Sri Dr Ali Hamsa and four decision makers in the Ministry of Health Malaysia (Media Suara Insan). This shows the critical need and claim for female doctors and nurses can work in maternity rooms and female ward.

Different things happen when there are groups propagating the issue of selection of delivery personel is a women's private right. They are free to choose who will manage their delivery and where to do. According to maqasid shariah perspective, the determination of maslahah and mafsadah aspects in the selection of delivery relates to the factor of preserving life and the necessity of maintaining dignity. These two factors are closely related to the strengths of doctors, midwives and nurses as well as those involved. Hence, there are two conditions that become the basis before the determination and selection are made. The condition is the condition of pregnant women who are in the category without risk factors or low risk and high-risk condition. Both of these conditions will differentiate the respective delivery personal. 
For women who are at low risk or without risk, it is adequate to be treated by a trained midwife only. While for high-risk cases, the involvement of a doctor or a specialist is required and sometimes will involve specialists in other fields such as anesthesia in surgery either in the case of emergency or an elective ceasarean (Malini, 2016). In this regard, the ruling of rukhsah in preserving the aurah and dignity of low-risk women is less as the midwife for handling low-risk delivery are female only. This means that maslahah in preserving the aurah (dignity) becomes priority when there is no conflict with the risk of life.

Hence, selecting different gender of doctor (male) for no risk or low-risk pregnancies that do not require certain expertise are contrary to the principles in maqasid shariah, that is maintaining maslahah and eliminating mafsadah. Rukhsah in disposing aurah during delivery to preserve the life (darurah) could be considered accordingly based on the fiqh method of الضرورة تقدر بقدرها. Beyond permissible limit occurs when the sequence of selecting nurses for female patients is the priority of female nurses (al-Sarkashi 1989; al-Kasani 2000) and there is no factor that allows them to choose a different gender personel except in the absence of a female doctor.

For women who are at high risk and need monitoring and involving doctors and specialists, the factor of preserving life becomes priority. Thus the ruling of rukhsah to open their private body (aurah) to achieve this objective but should bel within the required limit. Doctors and specialist who handle high-risk delivery are women and men. Prioritizing female doctors remains a priority except when there are other factors preventing this first step as in the absence of female doctor when the procedure is conducted or requires certain expertise only belonging to male doctor despite the different religions. Therefore, there are two permissible rukhsah at this time, namely rukhsah in opening aurah and rukhsah in getting treatment from other different gender. This approach uses the approach between mafsadah in opening aurat and mafsadah getting treatment from male personel.

In relation to the conflict between delivery personel and women's dignity, using the ruling of rukhsah accordingly could lead to achieving the maqasid rather than maintaining the ruling of 'azimah in the delivery process, especially in cases of high-risk and emergency births. The issue of personnel's gender is not major when the expertise and skills are needed to save the lives. Therefore, the role and knowledge in medicine become priority. This knowledge can only be practiced by those who have knowledge and skills in the field of medicine because it involves the safety of human life. Therefore, it is permissible for male nurses to treat female patients and vice versa as Rasulullah SAW permitted Umm Salamah to do cupping by Abu Taybah. In other case the women were allowed to give treatment to men during the war as narrated in the prophet's saying:

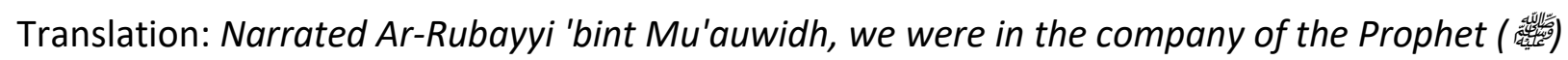
providing the wounded with water and treating them and bringing the killed to Medina (from the battle field) . (Hadith Narrated by al-Bukhari, Kitab al-Tibb, Bab Hal Yudawi al-Rajul al-Mar'ah aw alMar'ah al-Rajul, no. Hadith 2726)

The above narration shows the medical need that allow the treatment process between different genders based on critical need and necessity (darurah) was permitted by the Prophet. 
Hence, choosing different gender of delivery personel while not requiring extensive expertise and experience is contrary to the concept of taking rukhsah (concession) for necessary as the figh method of emergency is limited to its rightful extent. In sum, the struggle for the right to choose the delivery personel can be followed if the right does not beyond the objective of Sharia of preserving soul and dignity as well as could not make the satisfactory aspect of service and conducive natal place as the basis.

\section{The Right to Choose the Delivery Method}

Delivery method refers to how the birth process takes place and is operated either normally or with the help of certain equipment and procedures. Nowadays, there are changes in the selection of delivery methods in line with the development of science and technology, lifestyle changes and socioeconomic factors of society. Selection of delivery methods directly affects mother and child mortality rates. The change from traditional home delivery method to hospitalization with the help of a sophisticated medical infrastructure reduces maternal mortality rate drastically in Malaysia, from 540 per 100000 births to 28 as recorded in 2010. (Yadav, 2012). However, the recent developments show re-emerging tendencies to choose the natural delivery method such as lotus birth that becaming hot issue recently.

The choice of cesarean and alternative delivery methods also seems to be the current trend with its own justification. Therefore, some terms related to delivery practices such as home birth, amani birth, water birth and lotus birth. This article will discuses two trends that becoming popular in the community namely the issue of home birth and the role of labour doula as well as the issue of lotus birth.

\section{Home Birth}

Home birth means giving birth in a residence whether it is planned or not, attended or unattended by well-trained midwife. Nothwithstanding Malaysia has achieved a safe birth rate comparable to a developed nation of $98 \%$ since 2009 with home-birth rates decreasing from $24.8 \%$ in 1990 to $1.7 \%$ in 2012 (Kementerian Kesihatan Malaysia), this issue again attracts public attention. Debates related to birth and its risk in other countries also focus on the issue of delivery options and the mothers' lifestyle. The choice of home birth in Malaysia is related to struggling for right to experience delivery naturally, then there is a group fighting for alternative method of birth. Alternative birth method means a delivery method apart from standard medical maternity practices set by MoH. This method is aimed at achieving natural or gentle births that naturally occur without any medicines and medical interventions. This group also uses doula services in managing this delivery. Doula is a lady trained to help laboring women as well as provide medical advice and moral support to them (Sandall et al., 2010).

The home birth struggle in Malaysia as reported in the mass, electronic and social media poses a conflict from the medical perspective as well as the perspective of maqasid al-shari'ah. In response to this issue, Minister of Health viewed as this choice of delivery is unsafe. According to WHO safe 
births are managed by skilled health personnel (World Health Organizaton, 2018) while home birth fought has only managed by a doula (birth companion or coach) who did not get the proper training.

The expertise and qualification factors of delivery personel is an important criterion in delivery because it is closely related to element of preserving soul (hifz al-nafs) either normal circumstances and more dominant when complications occur. Hence, the regulations set by the $\mathrm{MOH}$ are only doctors and health professionals registered with the Malaysian Midwives Board and trained in the field of maternity only who can handle delivery is sadd al-dhari'ah step to the risk of maternal and child life threats during delivery. This is clearly stated in the Act 436 Midwives Act 1966 Part V Section 14 (1) below;

"Any person who, not being a midwife registered under this Act, practices midwifery, shall be guilty of an offence and shall be liable on conviction to a fine not exceeding two thousand ringgit or to imprisonment for a period not exceeding one year or to both."

(Midwives Act 1996 (Akta 436)

In relation to that, the birth personel's eligibility and knowledge factors become indicators to determine the standard of maslahah and mafsadah for the labour at home or residence. If home birth method hasufficient equipment facilities and operated by a trained personel and the labour women at their health status without risk factor, then the home birth is permissible because it considers the elements that could eliminate or minimize mafsadah. This is in line with the general principles of the Sharia that is denying the harm and creating harmful situation. Therefore, if home birth brings mafsadah to the mother and the baby then it is obligatory to choose the method that can eliminate or minimize such mafsadah such as delivery at the hospital. Thus, the views and advices of ahl al-zikr are compulsory because in the medical context, this group of experts consists of doctors who have knowledge and practice them according to their expertise.

In conclusion, the home birth issue has its own standard of maslahah and mafsadah that is determined according to the factors supporting the process of this delivery method. Fectors of personel, equipment and safety as well as Standard of Operatoion (SOP) are applied as the basis of assessment. The reason for the natural birth struggle and the personal right to choose maternity merely leads to greater mafsadah if these factors are neglected. Hence, identifying the aspects of maslahah and mafsadah before making decisions on this issue is an obligation as it involves the safety of mother and child as concerned by the $\mathrm{MOH}$ and Sharia.

\section{Lotus Birth}

Lotus Birth is a birth method that maintains the cord attached to the baby after the baby coming out (without cutting the cord) and letting the umbilical cord off by itself. The justification for this method is based on the faster release period of the placenta and the umbilical cord as well as the close relationship factor between the newborn baby and her mother. The findings in Indonesia shows that 
the umbilical cord will be fastly detached about 3 to 7 days after the baby is born and is speedily drying in the lotus birth compared to the umbilical cord immediatedly cut off after the delivery.

The findings also show that there are significant differences between these two methods in terms of the release period of the placenta and the umbilical cord. In addition, the relationship between mother and child in the Lotus Birth method is better than the normal labour method. The lotus birth practictioners also claim that when the umbilical cord is not cut off, the mother's blood flow to the fetus continues. Hence, oxygen is still supplied to the baby through the umbilical cord before the babies can start breathing on their own. Another benefit of this Lotus Birth method is that it allows the baby to quickly cry after birth and is still close to his mother after being born (Lia Ratnasari et.al, 2013). This condition is considered to produce longer bounding attachment between mother and baby.

Current developments in Malaysia show the reactions that support this birth method and are being popularized in society. This action received various feedback from many parties and the analysis was made by referring to experts' opinions in medicine. The responses indicate that there are different views regarding this issue in terms of the safety of this practice as well as the doubt of its positive point of view as mentioned earlier. The responses obtained from interviews with experts, through printed, electronic and social media, show the lotus birth method has more negative than positive impacts. Thus the struggle to practice the method of birth lotus on the basis of reproductive rights is not desirable nowadays because this method of birth contradicts to the Quranic priciples.

From the light of maqasid Shariah, the choice of maternity methods is assesed according to the extent of this decision can lead to maslahah (the common good) and mafsadah (harm) to the women. As the aspect of preserving life (hifz al-nafs) is a major consideration in the issue of birth, thus the choice of delivery method also considers the same approach that minimizes the threats to the lives of mother and baby.

\section{Analysis of Reproductive Rights Struggle According to the Al-Quran}

Based on the above discussion relating to the issue of the reproductive rights struggle, it is analyzed its contradiction with the Holy Quran in two fundamental principles;

\section{i. The Honour of life (nafs)}

The honour of life meant is the right to life which is one of the five essentials preserved by Shariah. In the struggle of reproductive rights related to abort to pregnancy, the issue of life preservation should be a priority when there is a conflict between the honor of the fetus and the personal interests which are not based on the right justification as discussed from the medical and legal perspective. This is consistent with Quranic verse 33 of surah al-isra as reference of struggling for reproductive rights in relation to the choices whether to continue or abort to pregnancy. Allah mentions in the Holy Quran: 
INTERNATIONAL JOURNAL OF ACADEMIC RESEARCH IN BUSINESS AND SOCIAL SCIENCES

Vol. 8, No. 11, Nov, 2018, E-ISSN: 2222-6990 @ 2018 HRMARS

Meaning : And do not kill the soul which Allah has forbidden, except by right. And whoever is killed unjustly - We have given his heir authority, but let him not exceed limits in [the matter of] taking life. Indeed, he has been supported [by the law].

al-isra', 17:33

Allah also affirms this matter in other Quranic verse that is:

Meaning : And indeed, it is We who give life and cause death, and We are the Inheritor. al-hijr, 15: 23

Based on the two above mentioned verses, the God commands the sacredness of life as the right of every servant and thus, any means to the preservation of life must be sustained while any means that threaten the life should be prevented. The struggle for the right to end the pregnancy is an extreme action that contradicted to the principle of the Holy Quran. However, the Shariah is fair and brings blessings when such act of abortion is permitted in case of

threating the other's life (mother).

\section{ii. The Honour of Dignity}

The honour of dignity is the second fundamental principles of the Holy Qur'an in dealing with the contemporary reproductive rights struggle. This principle should be a framework for an action based on personal interest like such struggle for reproductive rights. For example, the right to choose the labour person in charge form different gender based on more convincing factor with the treatment provided meanwhile there is no risk factor that requires specialist services that may be available to male doctor or nurse. This action put the element of preserving dignity after the need for tahsiniyyat that is choosing doctor or nurse with same gender. Although this action does not involve the other's rights, but the fundamental principle highlighted by the Holy Quran emphasizes this element in line with human studies as the best of creation. Hence the action beyond the framework of preserving dignity does not meet the principle of man as the best creation.

In this regard, human rights struggle must be adapted in accordance with God's word that is:

Meaning : Allah has promised those who have believed among you and done righteous deeds that He will surely grant them succession [to authority] upon the earth just as He granted it to those before them and that He will surely establish for them [therein] their religion which He has preferred for them and that He will surely substitute for them, after their fear, security, [for] they worship Me, not associating anything with Me. But whoever disbelieves after that - then those are the defiantly disobedient. al-Nuur, $24: 55$ 
The fundamental principle of the Qur'an elucidates a framework that underlies the struggle of women for their reproductive rights. Both principles are elements to meet the objectives of Islamic law that based on the Quran and Hadith. Adherence to this principle benefits the mukalaf (religiously accountable) in making the right choices.

\section{Conclusion}

In Islam, when people freely struggle for 'their own' rights, this should be firstly justified the consistency of such right with Allah's commandments and prohibitions. It is not permitted if struggling for rights that are contradicted with Islamic values and principles as well as denying the rights that are promoted in Islam. Such struggle will violate the Islamic sacredness and its relevancy especially in the context of Islamic jurisprudence and law. To acknowledge a struggle for rights to be compatible with the Islamic principles, it should be based on the underlying foundations of Islamic law or five essentials (daruriyyat al-khamsah) namely the preservation of religion, life, wealth, intellect and progeny.

This is because the struggle that denies these essentials will create conflicting conditions in managing one's personal affairs, family, community and society. For example, a struggle for human rights that do not reflect the preservation of religious ethics such as the freedom of transgender will give implications on disorder in society such as gender marriage, gender mixing in the worship space in the mosque, misdistribution of inheritance, giving witnesses, unintentionally mixing, religious rights such as Friday prayers, the leader of prayers and such other negative implications. However, if people obey the Islamic law and principles, they will enjoy their basic rights harmoniously because the laws never prevent a man from converting religion that suit his nature, enjoying food and drink, sleeping, moving, seeking wealth, giving birth, thinking and so on. While the forbidden human rights struggle such as associating the God, abuse, murder, bribery, corruption, robbery, adultery, threatening souls, taking intoxicants and so on.

Such struggle for rights should be carefully managed to avoid misunderstandings and wrong doing among members of this contemporary society. It should be noted that bounty of blessings bestowed by God on His creatures should be benefitted in accordance to Islamic law. The struggle based on western ideology will eventually create destruction in one's life. Every right and trust given by the God will be questioned in the Hereafter. Hence, human rights are not absolute, but considered as divine trust to human beings on the earth. The human rights regulated by the Islamic law could not be freely amended as these rights determined by the authoritative sources namely the Holy al-

Quran and the traditions of the prophet.

\section{ACKNOWLEDGEMENT}

This paper is founded on the research project of the Special Research Grant Scheme (SRGS)UniSZA/SRGS-FKI/2018/04, entitled: 'Pembinaan Model Pengendalian Rawatan Materniti Yang Holistik Di Malaysia'. Special appreciation is owed to Universiti Sultan Zainal Abidin (UniSZA) for sponsoring and supporting this research. 
INTERNATIONAL JOURNAL OF ACADEMIC RESEARCH IN BUSINESS AND SOCIAL SCIENCES

Vol. 8, No. 11, Nov, 2018, E-ISSN: 2222-6990 (C) 2018 HRMARS

\section{Corresponding Author}

Dr. Siti Khatijah Ismail, phD is Senior lecturer at Faculty of Islamic Contemporary Studies, Universiti Sultan Zainal Abidin Malaysia.

Emeil: khatijah@unisza.edu.my

\section{References}

AbdulRahman, A. (2006). Human Rights: An Islamic Perspective. Jurnal Syariah. 14 (Jan-Jun 2006).

AbuFaris, M.A.Q. (2000). Huquq al-Mar'ah al-Madaniyyah wa al-Siyasiyyah fi allslam. Urdun: Dar alFurqan.

Al-Barr, M. (1995). Khalq al-Insan Bayn al-Tibb wa al-Quran. Jeddah: Al-Dar alSu'udiyyah.

Al-Hanbaliy, M. (1987). Kitab al-Fatawa Mukhtasar alMisriyyah-al-Tashil. Beirut: Dar al-Jil.

Al-Kasani. (2000). Bada'i al-Sana'i fi Tartib al-Shara'i. Beirut: Dar Ihya' al-Turath al-'Arabi.

Al-Mani', A. A.A. (2013). Fatawa al-Lajnah al-Daimah li al-Fatwa fi Imarah al-Shariqah. Sharjah: AlAmanah al-'Amah li al-Awqaf bi al-Shariqah.

Al-Ramli, S.M. (1967). Nihayah al-Muhtaj ila Sharh al-Minhaj (Mesir: Maktabah wa Matba'ah Mustafa al-Babi al-Halabi wa Awladih.

Al-Sarkashi, S. (1989). Kitab al-Mabsut. Beirut: Dar al-Fikr.

Al-Zuhayli, M. (2011). Al-Mu'tamad fi al-Fiqh al-Shafi'i. Damshiq: Dar al-Qalam.

Anon. (2018). Reproductive Rights Advocacy Alliance Malaysia. Retrieved 24 October 2018, from http://www.rraam.org/.

Anon. (2018). Vision and Mission of SUHAKAM. Retrieved 24 October 2018, from http://www.suhakam.org.my/.

Brokers, B. (2013). Abortion In England 1900-1967. New York: Routledge Library Editions.

Chandrasekhan, S. (1974). Abortion in a Crowded World (London: George Allan \& Unwin Ltd..

Government of Malaysia. Reports on the Confidential Enquiries into Maternal Deaths in Malaysia 2009-2012. Kuala Lumpur: Family Health Development Division, Ministry of Health, Malaysia, 2014.

Hamat, M.F. (2007). Hak asasi manusia menurut syarak. Jurnal Penyelidikan Islam, Vol. 20. 45-66.

Mustafa, I., 'Ali, M., al-Qadir, H.A., \& Hasan, A. (1972). Al-Mu'jam al-Wasit. Istanbul: Al-Maktabah alIslamiyyah.

Kaczor, C. (2015). The Ethics of Abortion Women's Rights, Human Life, And The Question of Justice, ed.-2 . New York: Routledge Library Editions.

Kartina, A.C. (2012). "Malaysia," in In International Encyclopaedia of Laws: Medical Law, ed. Herman Nys. Alphen aan den Rijn. Netherlands: Kluwer Law International.

Laws of Malaysia Act 597 -Human Rights Commission of Malaysia Act 1999 (Malaysia).

Ratnasari, E.L.S., Andita W. and Nurul E.W., (2013). Pengaruh Persalinan Lotus Birth Terhadap Lama Pelepasan Plasenta, Lama Pelepasan Tali Pusat dan Keberhasilan Bounding Attachment. Jurnal Kebidanan. Volume 5, No.2.

MacLaren, A. (1978). Birth Control in Nineteenth-Century England.London: Croom Helm.

Mansureh, Y., Abolghasem, P., Arezoo, P., and Fatemeh, A. (2015). Unintended Pregnancy and Its Adverse Social and Economic Consequences on Health System: A Narrative Review Article. Iranian Journal of Public Health, 44(1): 12-21. 
INTERNATIONAL JOURNAL OF ACADEMIC RESEARCH IN BUSINESS AND SOCIAL SCIENCES

Vol. 8, No. 11, Nov, 2018, E-ISSN: 2222-6990 @ 2018 HRMARS

Mazni, N. \& Anisah, C. N. (2011). Skop Kelakuan Buruk Dalam Kod Kelakuan Profesional 1987: Satu Analisis Menurut Etika Perubatan Islam. Jurnal Undang-Undang dan Masyarakat, 15 . pp. 5374. ISSN 1394-7729.

Sandall, J., Morton, C. and Bick, D. (2010). "Safety in Childbirth and The Three 'C's: Community, Context and Culture," Midwifery 26, 5, 481-182.

Siti Khatijah, I. and Mohd. Badrol, A. (2013). Pengguguran dan Justifikasi Perundangan mengikut Undang-undang Islam dan Peruntukan 312. Jurnal Islam dan Masyarakat Kontemporari. Jilid 6 (Julai), 2013, 13-246.

Stanislaw, J., Frankoskwi and George, F. (1987). Abortion and Protection of the Human Fetus. Leidin, Boston: Martinus Nijhoff Publishers.

Tussaripah, M., Mukti, A. \& Satari H. (2012). Pengguguran Bayi Menurut Perspektif Islam dan Perundangan di Malaysia. Global Journal of Al-Thaqafah (GJAT). Vol. 2. No. 1. 69-83.

Warren, M.A. (1996)."On the Moral and Legal Status of Abortion," in Biomedical Ethics, ed. T.A. Mappes and D. DeGrazia. New York: McGraw-Hill, Inc.

World Health Organization. (2018). WHO Safe Childbirth Checklist. Retrieved 24 October 2018, from http:// www.who. int/patientsafety/policies/en/

Yadav, H. (2012). A Review of Maternal Mortality in Malaysia. IeJSME Special Issue.2012. Vol 6(Supp 1):. S142-S151. 